NBER WORKING PAPER SERIES

ECONOMIC EXPANSIONS ARE UNHEALTHY: EVIDENCE FROM MICRODATA

Christopher J. Ruhm

Working Paper 8447

http://www.nber.org/papers/w8447

\author{
NATIONAL BUREAU OF ECONOMIC RESEARCH \\ 1050 Massachusetts Avenue \\ Cambridge, MA 02138 \\ August 2001
}

I thank McKinley Blackburn, Donna Gilleskie, Mark Loewenstein, Ken Snowden, and seminar participants at the Southern Economic Association Meetings, International Health Economics Association Third International Conference, University of South Carolina, and the Duke-UNC Health Workshop for helpful comments and William Black for research assistance. Financial support from the National Science Foundation (SES9876511) is gratefully acknowledged. The views expressed herein are those of the author and not necessarily those of the National Bureau of Economic Research.

(C) 2001 by Christopher J. Ruhm. All rights reserved. Short sections of text, not to exceed two paragraphs, may be quoted without explicit permission provided that full credit, including (C) notice, is given to the source. 
Economic Expansions Are Unhealthy: Evidence from Microdata

Christopher J. Ruhm

NBER Working Paper No. 8447

August 2001

JEL No. E32, I12

\begin{abstract}
$\underline{\text { ABSTRACT }}$
This study uses microdata from the 1972-1981 National Health Interview Surveys to examine how health status and medical care utilization fluctuate with state macroeconomic conditions, after controlling for personal characteristics, location fixed-effects, general time effects and (usually) statespecific time trends. The major finding is that there is a countercyclical variation in physical health that is especially pronounced for individuals of prime-working age, employed persons, and males. The negative health effects of economic expansions accumulate over several years, are larger for acute than chronic ailments, and occur despite increased use of medical care. Finally, there is some evidence that mental health is procyclical, in sharp contrast to physical well-being.
\end{abstract}

Christopher J. Ruhm

Department of Economics

Bryan School

UNCG

P.O. Box 26165

Greensboro, NC 27402-6165

and NBER

Tel: (336) 334-5148

Fax: (336) 334-4089

Email: C_RUHM@UNCG.EDU 


\section{Economic Expansions Are Unhealthy: Evidence from Microdata}

Widely cited analyses of aggregate time-series data by Harvey Brenner (1973, 1975,

1979) reveal a countercyclical variation in admissions to mental hospitals, infant mortality rates, and deaths due to cardiovascular disease, cirrhosis, suicide, and homicide. However, this research suffers from serious technical flaws (Gravelle, et al., 1981; Stern, 1983; Wagstaff, 1985; Cook \& Zarkin, 1986) and studies correcting the problems (Forbes \& McGregor, 1984; McAvinchey, 1988; Joyce \& Mocan, 1993) fail to uncover a consistent relationship between the macroeconomy and health. ${ }^{1}$ Instead, the results are sensitive to the choice of countries, time periods, and outcomes, with falling unemployment frequently being correlated with worse rather than better health. The lack of robustness is not surprising, since any lengthy time-series may

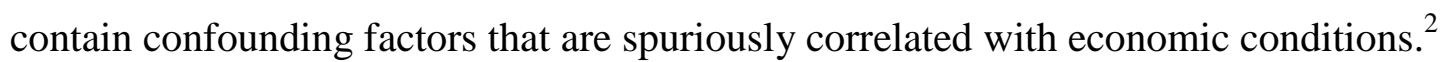

Ruhm (2000) has addressed the omitted variables bias issue by estimating fixed-effect (FE) models for a panel of the 50 states and District of Columbia over a 20-year period (19721991). These specifications exploit within-state changes and so automatically hold constant all time-invariant factors that are spuriously correlated with economic conditions across locations. Strong evidence is provided that mortality increases when the economy temporarily improves. Unemployment is negatively and significantly related to total mortality and 8 of 10 specific causes of fatalities, with suicides the important exception. For instance, a one percentage point increase in the state unemployment rate is associated with $0.5,3.0,0.7$, and 0.4 percent decreases in deaths from all causes, motor vehicle fatalities, flu/pneumonia, and heart disease.

\footnotetext{
${ }^{1}$ Criticisms of Brenner's research include his method of choosing lag lengths, the hypothesized pattern of lag coefficients, choice of covariates, and the plausibility of his results.

${ }^{2}$ For example, much of the variation in unemployment occurring during the four decades (beginning in the 1930s) covered by Brenner's research resulted from dramatic reductions in joblessness following the great depression. During this same period, health improved due to better nutrition and increased availability of antibiotics. Failure to control for these factors leads to an overstatement of the detrimental health impact of unemployment.
} 
However, at least two important questions remain unanswered. First, it is possible that deaths are procyclical but other aspects of health are not. For example, accident fatalities exhibit a particularly strong variation but may be only weakly related to previous health status. ${ }^{3}$ Second, individual-level relationships can not be ascertained using aggregate data. Thus, the macroeconomic effects could vary by age, sex, ethnicity, or employment status. This is the "ecological inference" problem. This investigation addresses these issues by using microdata, for persons aged 30 and over from the 1972-1981 years of the National Health Interview Survey (NHIS), to examine how health fluctuates with state economic conditions after controlling for personal characteristics, time-invariant factors, general time effects, and (usually) state-specific time trends. The proxies for health include specific morbidities, activity limitations, selfassessments of overall status, and medical care utilization. The relationships are examined for the full sample and for subgroups.

The major findings are as follows. First, most measures of health decline when economic conditions improve. A one percentage point drop in the state unemployment rate is associated with a statistically significant 1.5 percent rise in the probability that respondents report one or more medical problems, a 1.5 percent increase in the number of ailments, a 1.7 (1.6) percent growth in the probability of one or more "restricted-activity days" ("bed-days") during the last two weeks, and modest elevation in the fraction claiming "poor" or "fair" (rather than "good" or "excellent") overall health. The cyclical variation is more pronounced for males, employed persons, and those of prime-working age than for their counterparts. ${ }^{4}$ Moreover, the negative

\footnotetext{
${ }^{3}$ Conversely, some medical problems (e.g. arthritis) probably have little effect on mortality. Small negative health shocks associated with transitory upturns may also cause frail persons to die slightly sooner than otherwise, while having little effect on overall population health.

${ }^{4}$ Since intrastate changes in economic conditions are examined, discussions of "cyclical" variations or "macroeconomic" effects refer to fluctuations within states rather than at the national level. Thus, the term "expansion" is used loosely to indicate the effects of a relative improvement in the state economy and does not refer to a technical definition based on changes in national GDP.
} 
health effects of sustained economic expansions accumulate over at least a two-year period and occur despite a procyclical variation in the use of medical care.

Second, the countercyclical fluctuation in health is much more pronounced for acute than chronic medical problems. Thus, the one point decline in unemployment raises the percentage of individuals predicted to have at least one acute (but no chronic) medical condition by a statistically significant 2.7 percent, while having virtually no effect on the prevalence of chronic problems. However, there is considerable variation across types of chronic ailments. For instance, the one point fall in joblessness is correlated with a 4.3 (8.7) percent rise in the frequency of ischemic heart disease (Intervertebral Disk problems) but a 7.2 percent decrease in non-psychotic mental disorders.

One concern is that worse measured health during good times might reflect better access to medical care (e.g. due to higher incomes or enhanced insurance coverage), resulting in improved identification of existing problems rather than a deterioration in actual status. The evidence does not support this possibility. The countercyclical variation is generally stronger for employed persons (for whom access to medical care is less of an issue) than for nonworking individuals and income is shown to have a protective effect on measured health.

\section{Why Might Good Economic Conditions Result in Bad Health?}

Many researchers have hypothesized that cyclical upturns benefit health by reducing the stress associated with economic insecurity (e.g. Brenner and Mooney, 1983; Catalano and Dooley, 1983; Fenwick and Tausig, 1994). However, there are at least three reasons why health might worsen during these periods. First, non-market "leisure" time decreases making it more costly for individuals to undertake time-intensive health-producing activities such as exercise. Consistent with this, preliminary analysis of data from the Behavioral Risk Factor Surveillance 
System (BRFSS) suggests that lower joblessness is associated with increases in smoking and obesity, reduced physical activity, and worse diets (Ruhm, 2000). ${ }^{5}$ Second, health may be an input into the production of goods and services. Most obviously, hazardous working conditions, the physical exertion of employment, and job-related stress could have negative effects, particularly when job hours are extended during short-lasting economic expansions (Baker, 1985; Karasek and Theorell, 1990; Sokejima and Kagamimori, 1998). Cyclically sensitive sectors, such as construction, also have high accident rates and some joint products of economic activity (e.g. pollution and traffic congestion) present health risks. ${ }^{6}$ Third, the higher incomes associated with good economic times may lead to increases in some risky activities (e.g. drinking, driving, or skiing), raising deaths from external causes such as motor vehicle fatalities (Evans and Graham, 1988; Ruhm, 1995; Freeman, 1999) and possibly elevating related non-fatal accidents and health problems.

The positive health effects of economic contractions need not be restricted to or even concentrated among those becoming newly unemployed. To the contrary, job loss could induce stress that counteracts other beneficial effects, raising the possibility that the unemployed get sick even while average health improves. ${ }^{7}$ Similarly, there is no reason to believe that all facets

\footnotetext{
${ }^{5}$ The time price of medical care may also decline, if persons working fewer hours find it easier to schedule medical appointments for themselves or their dependents. Consistent with this, Mwabu (1988) and Vistnes and Hamilton (1995) report a negative relationship between employment and the utilization of medical care.

${ }^{6}$ For instance, Chay and Greenstone (1999) show that county-level reductions in pollution associated with the 19811982 recession led to substantial decreases in infant mortality.

${ }^{7}$ There is no doubt that the nonemployed are in worse average health than workers (e.g. Morris, et al., 1994; Currie and Madrian, 1999; Ettner, 2000). However, since poor health probably reduces employment probabilities, the direction of causation is poorly understood (Bartley, 1996; Goldney, 1997). Martikainen and Valkonen (1996) examine this issue by comparing the mortality rates of persons losing jobs in Finland during times of relatively low and high joblessness. Consistent with their hypothesis of stronger selection during good times, they find that the association between unemployment and subsequent mortality weakens as joblessness rises.
} 
of health respond in the same way. For instance, increasing stress provides one reason why mental health might deteriorate despite gains in physical well-being. ${ }^{8}$

Finally, it should be emphasized that health problems associated with transitory expansions do not imply negative effects of permanent economic growth. The key distinction is that agents have greater flexibility in making consumption, time-allocation, and production decisions in the long-run. For example, temporary increases in output usually involve greater use of labor and health inputs with existing technologies. Conversely, permanent growth results from technological improvements or expansions in the capital stock that, by pushing out the production possibility frontier, have the potential to ameliorate or eliminate any costs to health. Similarly, individuals are more likely to defer health investments in response to temporary than permanent increases in work hours and sustained income growth permits purchases of consumption goods (such as vehicle safety) that improve health. ${ }^{9}$

\section{Econometric Methods}

The basic regression specification estimated below is:

$$
\mathrm{H}_{\mathrm{ijt}}=\alpha_{\mathrm{t}}+\mathrm{X}_{\mathrm{ijt}} \beta+\mathrm{E}_{\mathrm{jt}} \gamma+\mathrm{S}_{\mathrm{j}}+\varepsilon_{\mathrm{ijt}},
$$

where $\mathrm{H}$ measures the health or medical care utilization of individual $\mathrm{i}$ in state $\mathrm{j}$ at time $\mathrm{t}, \mathrm{X}$ is a vector of personal characteristics, $\mathrm{E}$ is the macroeconomic variable (typically the unemployment rate), $\alpha$ is year-specific intercept, $S$ a state fixed-effect, and $\varepsilon$ is a disturbance term.

The year effect holds constant determinants of health that vary uniformly across states over time; the fixed-effect accounts for those that differ across locations but are time-invariant.

\footnotetext{
${ }^{8}$ Jobless persons are more likely than employed individuals to be mentally ill or to commit suicide (Dooley, et al., 1988; Catalano, 1991; Lewis and Slogget, 1998; Mortensen, et al., 2000). While it is difficult to infer causation from these studies, a careful investigation by Hamilton, Merrigan, and Dufresne (1997) finds a detrimental effect even after accounting for the endogeneity between mental illness and unemployment.

${ }^{9}$ Ettner (1996) or Pritchett and Summers (1996) provide examples of research showing a positive relationship between lasting increases in income and health status. Graham, Chang, and Evan's [1992] analysis of U.S. time-
} 
Therefore, the impact of the macroeconomy is identified by within-state variations in economic conditions, relative to the changes occurring in other states. Most of the estimates also include a vector of state-specific linear time trends $\left(\mathrm{S}_{\mathrm{j}} * \mathrm{~T}\right)$, to control for factors that vary over time within states, implying the regression equation:

$$
\mathrm{H}_{\mathrm{ijt}}=\alpha_{\mathrm{t}}+\mathrm{X}_{\mathrm{ijt}} \beta+\mathrm{E}_{\mathrm{jt}} \gamma+\mathrm{S}_{\mathrm{j}}+\mathrm{S}_{\mathrm{j}} * \mathrm{~T}+\varepsilon_{\mathrm{ijt} .}{ }^{10}
$$

For ease of interpretation, the results of linear probability models are presented for the dichotomous outcomes; however, very similar effects are predicted using corresponding binary probit models. Tobit estimation is used when the dependent variable is continuous but censored at zero (e.g. the number of restricted-activity days). All of the estimates weight the observations to account for unequal probabilities of being included in the sample. Robust standard errors are calculated using the Huber-White sandwich estimator. ${ }^{11}$

\section{Data}

Data are from the 1972-1981 years of the National Health Interview Survey (NHIS), which is conducted by the National Center for Health Statistics at the Centers for Disease Control and Prevention. The NHIS is designed to assess the amount and distribution of illness, disability, and chronic impairments of the civilian noninstitutionalized population of the United States, as well as the type and duration of health services received by them. ${ }^{12}$ Most of the data come from the NHIS Cumulative Core File (CCF), compiled by the Inter-University Consortium

series data indicates that mortality rates are negatively (positively) related to permanent (transitory) income as proxied by per capita consumption (the inverse of unemployment).

${ }^{10}$ A potential issue is that the state-specific trends might absorb most of the within-state variation in unemployment rates. This problem does not appear to be severe. The addition of trends eliminates less than 38 percent of the variation in unemployment rates remaining after including general year and state fixed-effects.

${ }^{11}$ I also sometimes calculated robust standard errors assuming independence of observations across states and months but not within states in a given month (because local unemployment or nonemployment rates take the same values for all individuals interviewed in a state during the same month). The resulting standard errors are typically 0 to 30 percent larger than those reported.

12 The web-site www.cdc.gov/nchs/nhis.htm contains further information on the NHIS. 
for Political and Social Research. The NHIS-CCF contains variables included in at least eight of the annual surveys taking place between 1969 and 1981 and includes persons aged 30 and over. ${ }^{13}$

One limitation is that the geographic information in the NHIS-CCF is restricted to the four census regions (Northeast, Midwest, South, and West). Since I am interested in determining how changes in local economic conditions affect health status, this level of aggregation is inadequate. Fortunately, the annual NHIS surveys (prior to 1984) identify the standard metropolitan statistical area (SMSA) for persons residing in 31 large SMSAs. ${ }^{14}$ This information was merged onto the Cumulative Core File to create geographic identifiers corresponding to the 20 states in which the 31 SMSAs are located. ${ }^{15}$

Data in the NHIS-CCF are quite old raising the possibility that the effects of interest may have altered over time, particularly for groups (such as women) with substantial changes in labor force participation.. More recent information could not be used, however, because geographic identifiers (beyond the census region) have been stripped off the public-use files after $1984 .^{16}$

\footnotetext{
${ }^{13}$ The "core" set of questions included in the NHIS was substantially changed in 1982, so that it is not possible to compare the information collected before and after that date. The years prior to 1972 are not used because data on self-assessed health status were not included and information on state unemployment rates is frequently unavailable. Further information on the NHIS-CCF can be obtained under study number 8629 in the archives section of the ISCPR web-site (www.icpsr.umich.edu).

${ }^{14}$ The SMSAs are: Boston, New York, Philadelphia, Pittsburgh, Detroit, Chicago, Cincinnati, Los Angeles-Long Beach, San Francisco-Oakland, Baltimore, Atlanta, Buffalo, Cleveland, Minneapolis-St. Paul, Milwaukee, Kansas City, St. Louis, Houston, Dallas, Washington, D.C., Seattle-Everett, San Diego, Anaheim-Santa Ana-Garden Grove, Miami, Denver, San Bernardino-Riverside-Ontario, Indianapolis, San Jose, New Orleans, Tampa-St. Petersburg, Portland (Oregon). Thirty-nine percent of the NHIS-CCF sample live in one of these SMSAs.

${ }^{15}$ Merging information on the SMSA of residence from the annual NHIS data sets to the Cumulative Core File required extracting from the annual 1972-1981 files (10 data sets) the SMSA, survey year, primary sampling unit, interview quarter and week, segment and household number, and the person number (within the household) for each respondent living in an identified SMSA. Since the same information (except for the SMSA) was available in the NHIS-CCF, individuals could be uniquely identified and the merge performed.

${ }^{16}$ A set of public use NHIS State Data Files, containing state identifiers, have been released for the years 19901994. However, these data are not useful for this analysis because: 1) the small number of years makes it difficult to separate the effects of secular trends from changes in macroeconomic conditions; 2) many of the variables in the full NHIS were deleted or converted from continuous to categorical variables; 3 ) it is not possible to link data files collected within a single survey year (e.g. the person, medical condition, or hospitalization files), so that individuallevel outcomes for many health variables of interest can not be constructed.
} 


\section{$\underline{3.1 \text { Outcomes }}$}

No single variable can capture all aspects of health. Therefore, the empirical work below examines a variety of outcomes, noting the strengths and weaknesses of each. The first set indicate the presence of medical conditions at the survey date. These include: a dichotomous measure of whether the respondent has at least one (acute or chronic) morbidity; a continuous indicator of the number of health problems; a binary outcome specifying the presence of one or more chronic ailments; and a dichotomous indicator of one or more acute (but no chronic) conditions. ${ }^{17}$ Forty-two percent of the sample have at least one morbidity. ${ }^{18}$ About half of these have a chronic problem and respondents average 0.7 medical conditions at the interview date.

The second group of dependent variables measure "restricted-activity days" and "beddays" during the two weeks preceding the survey. In each case, a binary variable indicates one or more limited days and a continuous measure denotes the number of such days (ranging from 0 to 14). Restricted-activity days are defined by a significant reduction in usual activities due to illness or injury. ${ }^{19}$ One issue is that a procyclical variation may be induced if health problems limit employment more than non-market pursuits, since working is more likely to be the "usual" activity in good times than bad. ${ }^{20}$ This is less of an issue for bed-days, which occur if the individual stays in bed for the majority of daylight hours due to illness or injury. ${ }^{21}$ Fourteen (7)

\footnotetext{
${ }^{17}$ Medical conditions are defined as departures from a state of physical or mental well-being as indicated by a positive response to one of a series of "medical-disability impact" or "illness-recall" questions. Acute morbidities have lasted less then 3 months and involved either medical attention or restricted activity. Chronic ailments have lasted more than 3 months but need not restrict activities. Certain conditions (arthritis, cancer, diabetes, heart trouble, or stroke) are defined as chronic regardless of the onset date. It is not possible to determine whether individuals with chronic conditions also have acute medical problems using the NHIS-CCF.

${ }^{18}$ All reported means are weighted using NHIS sampling weights. The unweighted estimates are generally similar.

${ }^{19}$ This does not require complete inactivity but the decrease must be significant.

${ }^{20}$ Chronic health conditions will also not be reflected to the extent that they permanently change the individual's usual activities.

${ }^{21}$ All days in the hospital are considered to be bed-days, even if the patient was not actually in bed more than half the day.
} 
percent of the respondents had at least one restricted-activity day (bed-day) and they averaged 0.9 (0.3) such days during the prior two weeks.

The third category of outcomes are dichotomous variables indicating poor and poor/fair (rather than good or excellent) self-reported overall health. Four percent of the sample rate their health as poor and 17 percent classify it as poor or fair. Previous research suggests that selfperceived health contains useful information (Bound, 1991; Idler \& Kasl, 1995; Idler \& Benyamini, 1997; Dwyer \& Mitchell, 1998). However, macroeconomic fluctuations may induce changes in reporting behavior that are unrelated to health status. For instance, individuals may become more pessimistic in bad times and so report worse health even if there has been no actual change in status. $^{22}$ I therefore place greater emphasis on the results for the more specific measures of health that are less likely to suffer from this problem. ${ }^{23}$

Fourth, the NHIS-CCF contains data on up to five specific chronic medical conditions that are a primary or secondary cause of activity limitations. This information, as coded under either the eighth or ninth revision of the International Classification of Diseases, was used to construct dichotomous variables for: Diseases of the Heart (Heart), Arthritis and Related Disorders (Arthritis), Chronic Obstructive Pulmonary Disease (Lung), Diabetes Mellitus (Diabetes), Circulatory System Disorders (Circulatory), Intervertebral Disk Disorders (Back), Cerebrovascular Disease (Stroke), Malignant Neoplasms (Cancer), Non-psychotic Mental

\footnotetext{
${ }^{22}$ Consistent with this, the dichotomous indicators of poor or poor/fair health are negatively correlated with the presence of acute medical conditions and only weakly positively associated with the activity limitations or chronic ailments. The full sample correlation between poor health and one or more medical condition, acute health problem, chronic ailment, bed-day, and restricted activity day is .227, -.072, .221, and .260. Di Tella, MacCulloch, and Oswald (2001) show that individuals report lower levels of "life satisfaction" during periods of cyclically high unemployment. It seems probable that self-assessments of overall health and life satisfaction are related. ${ }^{23}$ Bound (1991) has raised concern that specific health conditions might measure some aspects of health well but others poorly. The comprehensiveness of the health information in the NHIS makes this less of an issue.
} 
Disorders (Neurosis), and Central Nervous System Disorders (CNS) ${ }^{24}$ These conditions are either major sources of adult deaths (Heart, Stroke, Cancer, Pulmonary, Diabetes) or have relatively high prevalence rates (Arthritis, Back, Neurosis, CNS, Circulatory) ${ }^{25}$ Ischemic heart disease (Ischemic) is also separately broken out from other heart problems, since it may be particularly responsive to changes in stress or lifestyles. ${ }^{26}$

Twenty-one percent of the NHIS-CCF sample have an acute health problem but no chronic ailment and another 21 percent have at least one chronic condition. A specific ailment is identified for 84 percent of the latter group (18 percent of the sample) and 74 percent of those with a described problem have one of the 10 specified chronic conditions. Heart disease has the highest prevalence rate (5.5 percent, 1.7 percent of whom have ischemic heart disease), followed by arthritis ( 3.7 percent), lung disease (1.3 percent), diabetes (1.2 percent), circulatory disorders (1.0 percent), back problems (1.0 percent), stroke ( 0.7 percent). neurosis ( 0.5 percent), and central nervous system ailments $(0.5$ percent $)$.

The fifth set of outcomes refer to the utilization of medical services. Two dichotomous variables measure if the respondent has been hospitalized or seen a doctor during the last year, and a continuous variable indicates the number of hospital episodes. ${ }^{27}$ Almost 12 percent of the sample spent time in the hospital and 76 percent went to a doctor in the 12 months prior to the survey.

\footnotetext{
${ }^{24}$ ICD-8 categories are used until 1978 and ICD-9 classifications thereafter. With the exception of back disorders, the ICD-8 and ICD-9 categories are the same for the conditions examined. The ICD groupings, shown in parentheses, are Heart (390-429), Arthritis (710-719), Lung (490-496), Diabetes (250), Circulatory (440-459), Back (ICD-8: 725; ICD-9: 722), Stroke (430-438), Cancer (140-208), Neurosis (300-316), and CNS (340-349).

${ }^{25}$ Several other conditions that are major causes of death (e.g. pneumonia/influenza; nephritis/nephrotic syndrome/ nephrosis; chronic liver disease/cirrhosis) were not separately analyzed because of their extremely low prevalence in the NHIS-CCF. Prevalence rates are also low for some conditions that are included, limiting the statistical power to reject the null hypothesis of no macroeconomic effects.

${ }^{26}$ The ICD categories for Ischemic Heart Disease are 410-414.

${ }^{27}$ Information on the number of physician visits is not provided.
} 
Ceteris paribus, healthier persons need less medical care. Higher use in good times therefore suggests worse health. However, utilization may alternatively rise because incomes grow or insurance becomes more available, so that the findings for medical care must be interpreted carefully. One strategy will be to focus on hospitalizations, which have a lower discretionary component than outpatient care. A second will be to examine the extent to which changes in utilization are explained by variations in incomes or direct measures of health status.

\subsection{Explanatory Variables}

State unemployment rates are the primary indicator of macroeconomic conditions below, although some specifications alternatively use the nonemployment rate (defined as the proportion of the population, rather than the labor force, not working). These variables were constructed using consistent unpublished data provided by the Bureau of Labor Statistics. ${ }^{28}$ The labor force data refer to calendar year averages, which are not ideal since respondents are surveyed throughout the year. For this reason, I used weighted averages of the current and previous year rates, calculated as:

$$
\left.\mathrm{E}_{\mathrm{i}}=\left[\left(\mathrm{M}_{\mathrm{i}} \times \mathrm{E}_{\mathrm{it}}\right)+\left(12-\mathrm{M}_{\mathrm{i}}\right) \mathrm{E}_{\mathrm{it}-1}\right)\right] / 12,
$$

where $\mathrm{M}$ is the interview month (equal to 1 in January and 12 in December) for individual i, E is the annual unemployment or nonemployment rate, and $t$ and refers to the calendar year of the survey. For example, weights on the current and prior year are $1 / 4$ and $3 / 4$ for individuals surveyed in March. This procedure places the greatest weight on the calendar year that includes the majority of the twelve months preceding the interview date. Some regressions also hold constant average real state per capita incomes (weighted as above and using data from the Bureau of

\footnotetext{
${ }^{28}$ I thank Edna Biederman of the BLS for supplying this information, which is calculated from the Current Population Survey and refers to noninstitutionalized persons aged 16 and over. Data are available starting in 1970 for most large states but not until 1976 for some smaller ones. No consistent series of SMSA-level employment data is available during the period of study, precluding an analysis of metropolitan area economic conditions.
} 
Economic Analysis) to examine the extent to which the macroeconomic fluctuations are explained by changes in incomes.

Supplemental covariates are also included. Dummy variables control for the age ranges (in years): 40-49, 50-59, 60-69, 70-79, and 80 or above, with 30-39 year olds the reference group. Five categorical variables for education are: high school dropouts (less than 12 years of completed education), some college (13-15 years), college graduates, graduate school attendees (17 or more years of schooling), and education not reported. High school graduates form the excluded category. The regressions additional incorporate dummy variables for veteran status, gender, two race variables (black and "other" nonwhite), central city residence, and three indicators of marital status (married, widowed, and separated/divorced). ${ }^{29}$ Finally, year and state dummy variables and (usually) state-specific linear time trends are included. Sample means for the full sample and subsamples stratified by age, sex, and employment status are displayed in Table A.1.

\section{Economic Conditions and Health Status}

Table 1 summarizes the results of econometric models estimating the relationship between economic conditions and health status. The first four columns refer to the full sample and the last two to persons employed at the survey date. The first and fifth columns exhibit the (weighted) mean values of the dependent variables; the others show predicted effects of a one percentage point increase in the state unemployment or nonemployment rate. For the dichotomous dependent variables, these are the regression coefficients from a linear probability model. When outcomes censored at zero (number of restricted-activity days, bed-days, or medical conditions) they are calculated as $\frac{1}{n} \sum_{\mathrm{i}=1}^{\mathrm{n}} \Phi\left(\mathrm{X}_{\mathrm{i}} \beta / \sigma\right) / \hat{\beta}_{\mathrm{k}}$, for $\hat{\beta}_{\mathrm{k}}$ the tobit coefficient on

\footnotetext{
${ }^{29}$ Ethnic status is not controlled for because it is unavailable until 1976 and inconsistently recorded after that time.
} 
unemployment or nonemployment and $\Phi($.$) the predicted probability of a non-censored$ observation. All models also control for individual characteristics, state fixed-effects, and year dummy variables. State-specific time trends are included in specifications (b) and (c). The state unemployment rate is the proxy for macroeconomic conditions, except for model (c), where nonemployment rates are utilized.

Most measures of health worsen when the economy strengthens. In model (a), a one percentage point fall in the state unemployment rate is associated with a statistically significant 0.36 percentage point rise in the probability of having one or more medical condition, an increase of 0.9 percent $(.0036 / .4185=.0086)$, and a 1.0 percent reduction in the number of morbidities. ${ }^{30}$ Specifications with state time-trends are less likely to suffer from omitted variables bias. Thus, it is noteworthy their inclusion leads to a larger 0.61 point (1.5 percent) predicted growth in the prevalence of medical ailments and a highly significant 1.5 percent increase in the number of conditions (model b). ${ }^{31}$ This is almost entirely due to the 0.56 percentage point (2.7 percent) elevation in the probability of acute problems. Conversely, there is essentially no change in expected frequency of chronic ailments although, as shown below, some specific conditions do become more common. The stronger response for acute than chronic morbidities makes sense, since the former are more likely to affected by transitory changes in stress, employment conditions, or lifestyles. ${ }^{32}$

Activity limitations also become more common in good times. In model (a), a one percentage point reduction in unemployment predicts a statistically significant .24 point (1.8

\footnotetext{
${ }^{30}$ All percentage changes are calculated at the sample mean of the dependent variable.

${ }^{31}$ The unemployment rate averages 7.01 percent (with a standard deviation of 1.61 percent). Thus, a one percentage point fall corresponds to a 14.3 percent decrease at the sample average. A 1.5 percent rise in the dependent variable therefore implies an unemployment elasticity of around -0.1 .
} 
percent) increase in the likelihood of restricted-activity days and a 2.0 percent elevation in the number of days. The relationship is weaker when state time-trends are included (specification b), but the probability of restricted-activity days still rises by .17 percentage points (1.2 percent) and the number of such days by 1.4 percent. The likelihood of bed-days is similarly predicted to grow by .14 percentage points ( 2.1 percent) and the number of days by 2.4 percent in model (a), compared to .11 points (1.6 percent) and 1.8 percent in specification (b). The relationship between economic conditions and self-assessed overall health is more ambiguous. When state time-trends are included, the fall in joblessness is unrelated to claims of poor health but is associated with a substantial increase in the fraction classifying their health as poor or fair. Controlling for nonemployment rather than unemployment yields similar results (see model c). The number of medical conditions is again predicted to rise sharply as the economy improves, dominated by increases in acute health problems. The procyclical variations in beddays and restricted-activity days are weaker than before, but that of self-assessed poor/fair overall health is more pronounced.

Restricted-activity days could become more common in good times because medical problems limit employment more than non-market activities, rather than because health deteriorates. Access to medical care may also improve during these periods, causing existing health problems to be revealed. The potential sources of bias should be substantially reduced by restricting the sample to workers, as is done in the last two columns of the table, since jobholders have relatively similar "usual" activities and employment is a major source of health insurance in the United States. However, the exclusion of nonworkers could mute the observed cyclical effects by removing much of the sample variation in health status. Conversely, the

\footnotetext{
${ }^{32}$ Results for the demographic covariates are generally as expected. Health is usually negatively related to age and positively correlated with education. Females, blacks, and unmarried (particularly divorced) individuals tend to be
} 
fluctuations might be larger if the negative health effects of economic upturns reflect increases in job-related stress or higher time costs of health investments for those employed long hours.

Workers are relatively healthy. Just 32 percent suffer from a medical condition and 9 percent rate their health as poor or fair (compared to 42 and 17 percent of the full sample). Nevertheless, most aspects of their health exhibit a particularly strong countercyclical variation. A one percentage point drop in unemployment is predicted to increase the prevalence of medical conditions by a statistically significant 0.75 percentage points $(2.3$ percent $) .{ }^{33}$ This is mostly due to a 2.9 percent rise in acute problems, although chronic ailments may also become more common. The likelihood of restricted-activity days grows by 0.22 percentage points $(2.3$ percent) and the number of such days by 2.1 percent. Weaker results are obtained for overall health status or bed-days, although the point estimates always suggest worse health.

\section{Medical Care}

Table 2 provides some evidence that the utilization of health services increases as the economy strengthens. For instance, in models that control for state time-trends (specification b), a one percentage point decline in unemployment is associated with an imprecisely estimated 0.11 point ( 0.9 percent) rise in the probability of hospitalization during the previous year, a 0.7 percent increase in the number of hospital episodes, and a 0.3 point ( 0.4 percent) growth in the likelihood of having visited a doctor.

The use of medical care might rise in good times because health insurance coverage or incomes increase. However, two factors make this doubtful. First, the cyclical variation is usually stronger among workers, for whom fluctuations in insurance coverage are less important, than for the full sample. Second, as shown in section 8, the unemployment coefficients are not

relatively unhealthy, as are residents of central cities. Table A.2 displays detailed findings for selected regressions.

${ }^{33}$ Unless otherwise noted, all remaining regressions include controls for state-specific time trends. 
affected by adding controls for personal income. Instead, it seems probable that more care is received during upturns because health deteriorates. In this regard, it is noteworthy that hospitalizations, which have lower demand elasticities than outpatient care (Manning et al., 1987) and so are more likely to reflect actual changes in health status, rise proportionately more than doctor visits. Direct evidence is provided in specification (d), which adds (two) dummy variables indicating whether the respondent suffers from acute ailments or chronic conditions. Persons with these health problems are much more likely to have been hospitalized or to have visited a doctor in the last year. ${ }^{34}$ Importantly, the inclusion of even these limited controls for health reduces the magnitude of the unemployment coefficient by one-third or more in almost all cases (compare models $b$ and d), verifying that a substantial portion of the variation in medical utilization is related to changes in underlying health.

\section{Subsamples}

Table 3 summarizes econometric findings for subsamples stratified by age, sex, and race. For purposes of brevity, the results for hospital episodes, restricted-activity days, and bed-days are limited to the dichotomous dependent variables. The first column restricts the sample to 3055 year old respondents of "prime working age", with the upper threshold chosen to avoid confounding the effects of interest with those of retirement. The next four columns provide separate estimates for males, females, whites, and blacks. ${ }^{35}$

Temporary economic upturns reduce the health of all of the subpopulations. Although small sample sizes often leads to imprecise estimates, limiting our ability to make comparisons across groups, there is some indication of relatively large macroeconomic effects for prime-age

\footnotetext{
${ }^{34}$ The presence of acute conditions is predicted to raise the probability of hospitalization (doctor visits), for the full sample, by a highly significant 6.1 (13.8) percentage points; chronic conditions are associated with even larger 17.1 (16.1) point increases. The p-value on the null hypothesis of no effect is always less than 001.

${ }^{35}$ Estimates are not presented for "other" nonwhites because of the small sample size for this group.
} 
adults and men. For example, a one percentage point drop in unemployment is associated with $0.6,0.7,0.2$ and 0.2 point $(1.9,3.6,1.5$, and 2.7 percent $)$ increases in the probability that $30-55$ year olds have medical conditions, acute morbidities, restricted-activity days and bed-days. These "effects" are one-quarter to two-thirds larger, in percentage terms, than those obtained for the full sample. The same fall in joblessness predicts a 3.2, 2.5, and 2.6 percent rise in acute ailments, restricted-activity days, and bed-days for males versus a $2.1,0.3$, and 0.8 percent growth for females. Mixed results are obtained for the race subgroups, with relatively large fluctuations in restricted-activity and bed-days more for whites and in specific medical conditions for blacks. Finally, the use of medical care services increases in good times for all groups but with some variation in the patterns of inpatient and outpatient care. ${ }^{36}$

\section{Specific Chronic Conditions}

Although the overall prevalence of chronic morbidities is essentially unrelated to economic conditions, variations are observed for some ailments. This is shown in Table 4 which, for expositional convenience, displays the expected effect of a ten (rather than one) percentage point rise in the state unemployment rate. The most noteworthy findings are the strong procyclical patterns of ischemic heart disease and intervertebral disk disorders - a one percentage point fall in unemployment predicts a 4.3 percent growth of the former and an 8.7 percent increase in the latter. Ischemic heart disease may rise in good times because income growth increases risky behaviors or because decreased leisure raises the time costs of health investments (like exercise). Back problems could become more common due to the physical strain of many types of employment, particularly as work hours increase.

Reduced joblessness is also associated with (statistically insignificant) higher rates of chronic obstructive pulmonary disease, stroke, and central nervous system disorders. By

\footnotetext{
${ }^{36}$ The one exception is that hospitalizations exhibit a statistically insignificant countercyclical variation for blacks.
} 
contrast, non-psychotic mental disorders decline by an almost significant 7.2 percent following a one percentage point drop in unemployment indicating that some types of mental health may vary procyclically. ${ }^{37}$ This suggests that previous research may correctly hypothesize a role for reduced stress during upturns, while mistakenly taking this to imply a more general improvement in health.

The prevalence of several chronic ailments (ischemic heart disease, stroke, and central nervous system disorders) rises more sharply during expansions for men than women. Further research is needed to determine if this reflects greater male involvement in the labor force or physiological differences between the sexes. ${ }^{38}$ One exception is that reduced joblessness is associated with a sharper growth in female cancer rates. Further analysis (not shown) reveals that this is largely due to a large rise in breast cancer (which is common in females but not males). It is possible that increased utilization of medical care, during good times, plays an important role in detecting this type of cancer. ${ }^{39}$

\section{Income Effects}

As mentioned, health could deteriorate when the economy improves because rising incomes lead to increases in risky activities like drinking, driving, and smoking. Conversely, earnings growth may have a protective effect (e.g. by allowing individuals to purchase safer cars) that is overwhelmed by heightened job stress or greater time costs of investing in healthpreserving activities. These issues are addressed in Table 5. Model (a) repeats the full sample findings presented above. Specification (b) summarizes the results for equations that add controls for per capita personal income (in thousands of \$1981).

\footnotetext{
${ }^{37}$ This is consistent with Ruhm's (2000) evidence that suicides (a proxy for mental health) are positively associated with unemployment rates, in contrast to the inverse relationship for other causes of death.

${ }^{38}$ For instance, premenopausal women rarely have heart attacks.
} 
Ceteris paribus, higher incomes are associated with improvements in almost all measures of health. As shown in the last column of the table, an extra thousand dollars reduces the predicted probability of medical conditions, acute ailments, restricted-activity days, and bed-days by a statistically significant $2.6,2.0,3.2$, and 2.3 percentage points $(6.3,9.7,23.6$, and 33.7 percent). ${ }^{40}$ The prevalence of poor overall health also declines by a marginally significant 0.6 points (13.6 percent), with small and statistically insignificant changes in the use of medical care. These results imply that the countercyclical variation in health would be even stronger were it not for the beneficial effect of income. Holding the latter constant, a one point reduction in unemployment increases the probability of medical conditions, acute problems, restrictedactivity days, and bed-days by $1.0,0.8,0.6$, and 0.4 percentage points $(2.3,4.0,4.5$, and 6.3 percent), which is 1.5 to 3.8 times larger than in model (a). This suggests that the negative effects of economic expansions result from some combination of greater time costs for making health-preserving investments and increases in job-related medical problems but not from higher incomes.

\section{Adjustment Paths}

Economic conditions have been assumed to have only a contemporaneous impact up to this point. There are at least two reasons why this might not be so. On the one hand, the effects of investments in health (such as diet, preventive medical care, or exercise) or job-related stress are likely to accumulate over time if these represent flows that gradually alter the stock of health capital (Grossman, 1972). This implies larger medium-term than short-run effects. On the other,

\footnotetext{
${ }^{39}$ Supporting this possibility, there is essentially no relationship between economic conditions and cancer for persons employed at the survey date.

${ }^{40}$ A $\$ 1000$ rise in incomes corresponds to an increase of 8.6 percent, implying that income elasticities exceed -1 for most of these measures of health. The $\$ 1000$ increase reduces the probability of chronic conditions by a statistically insignificant 3.0 percent. Estimates on specific chronic conditions reveal a negative (although often insignificant) income effect for arthritis, diabetes, circulatory problems, and stroke. A positive income effect is predicted for nonischemic heart disease, lung disease, neurosis, and central nervous system disorders.
} 
agents have greater flexibility in making consumption, time allocation, and production decisions in the long-run than initially, suggesting that permanent growth of incomes will eventually improve most aspects of health.

The dynamics of the adjustment process are examined by estimating equations that include lagged unemployment rates. Table 6 uses the results of models that contain one and twoyear lags, as well as current unemployment, to show the predicted impact of a one percentage point increase in joblessness that begins in year $\mathrm{t}$ and is sustained through $\mathrm{t}+2{ }^{41}$ There is some variation across outcomes but most of the findings imply larger effects on health after two years than initially. For instance, a lasting one point fall in unemployment is associated with a .97 percentage point ( 4.7 percent) growth in the prevalence of acute medical problems after two years, which is 64 percent greater than the contemporaneous effect. Similarly, the probability of bed-days increases by .24 percentage points ( 35.8 percent) after two years, compared to .14 percentage points (20.9 percent) initially.

Some information on longer-term adjustments was obtained by estimating models that include up to a four-year lag of the unemployment rate. The findings (not shown) suggest that most of the changes in health predicted after two years continue or even grow by the end of four years. For instance, the four-year reduction in the predicted probability of acute conditions is 24 percent greater than the effect expected after two years. ${ }^{42}$ However, these results should be interpreted cautiously since the absence of consistent unemployment data prior to 1970 implies considerably reduced sample sizes for these specifications and more limited within-state variations in economic conditions.

\footnotetext{
${ }^{41}$ This is estimated as the sum of the unemployment coefficients for years $t, t-1$, and $t-2$.

${ }^{42}$ This contrasts with evidence provided by Ruhm (2000) of greater impacts on most types of mortality after two years than after four. Models that included a one-year lead of the unemployment rate were also estimated to provide a crude test of reverse causation. The lead coefficient was always of small size and statistically insignificant.
} 


\section{Discussion}

Most aspects of health appear to worsen when the economy temporarily improves. For instance, a one percentage point fall in the state unemployment rate is predicted to raise the prevalence of medical problems by 1.5 percent, restricted-activity days and bed-days by 1.2 and 1.4 percent, and ischemic heart disease or intervertebral disk disorders by 4.3 percent and 8.7 percent. The countercyclical variation is particularly strong for persons of prime working age, employed individuals, and men. It occurs despite a protective effect of income and a procyclical fluctuation of medical care. Moreover, the detrimental health consequences generally appear to accumulate over time, resulting in larger medium-term than short-run effects.

It is noteworthy that economic expansions are associated with increases in medical problems that are unrelated to mortality (e.g. back ailments) as well as those that are major causes of death (e.g. ischemic heart disease). Conversely, non-psychotic mental disorders become less common when the economy strengthens. This emphasizes the distinction between physical and mental health and lends credence to psychological theories relating stress to economic insecurity. Nevertheless, any reductions in stress during good economic times appear to be more than offset for by other changes that result in deteriorations in most aspects of health.

We need to better understand the sources of the countercyclical variation in physical health. Some of it is almost certainly due to risks directly associated with heightened economic activity (e.g. increases in workplace accidents and highway vehicle fatalities). Lifestyle factors and health investments may also play a role. For instance, Ruhm (2000) finds that upturns are associated with increased smoking, reduced exercise, and heightened obesity. More medical care is also used in good times. Although this is partly due to worsening health, a portion may 
represent investments in preventive care that have a longer-term payoff. These represent fruitful areas for future study. 


\section{References}

Baker, Dean B. 1985. "The Study of Stress at Work” Annual Review of Public Health, 6, 367-81.

Bartley, Mel. 1996. "Unemployment and Health Selection” The Lancet, 348, October 5, 904.

Brenner, M. Harvey. 1973. Mental Illness and the Economy. Cambridge: Harvard University Press.

Brenner, M. Harvey. 1975. "Trends in Alcohol Consumption and Associated Illnesses: Some Effects of Economic Changes" The American Journal of Public Health, 65(12), 1279-92. $(1975 b)$

Brenner, M. Harvey. 1979. "Mortality and the National Economy" The Lancet, September 15, 568-73.

Brenner, M. Harvey and Anne Mooney. 1983. "Unemployment and Health in the Context of Economic Change” Social Science Medicine, 17(16), 1125-38.

Bound, John. 1991. "Self-Reported Versus Objective Measures of Health in Retirement Models" Journal of Human Resources 26(1), 106-138.

Catalano, Ralph. 1991. "The Health Effects of Economic Insecurity” American Journal of Public Health, 81(9), 1148-1152.

Catalano, Ralph and David Dooley. 1983. "Health Effects of Economic Instability: A Test of the Economic Stress Hypothesis" Journal of Health and Social Behavior, 24 (March), 46-60.

Chay, Kenneth Y. and Michael Greenstone. 1999. “The Impact of Air Pollution on Infant Mortality: Evidence from Geographic Variation in Pollution Shocks Induced By a Recession,” National Bureau of Economic Research Working Paper No. 7442.

Cook, Philip J. and Gary A. Zarkin. 1986. "Homicide and Economic Conditions: A Replication and Critique of M. Harvey Brenner's New Report to Congress" Journal of Quantitative Criminology, 2(1), 69-80.

Currie, Janet and Brigitte C. Madrian. 1999. "Health, Health Insurance and the Labor Market" in Orley C. Ashenfelter and David Card (eds.), Handbook of Labor Economics, Vol. 3c, Amsterdam: Elsevier Science B.V., 3309-3416.

Di Tella, Rafael, Robert J. MacCulloch, and Andrew J. Oswald. 2001. "Preferences Over Inflation and Unemployment: Evidence from Surveys of Happiness" American Economic Review, 91(1), 335-341.

Dooley, David, Ralph Catalano, Karen Rook. 1988. "Personal and Aggregate Unemployment and Psychological Problems" Journal of Social Issues, 44(4), 107-23. 
Dwyer, Debra S. and Olivia S. Mitchell. 1998. "Health Problems as Determinants of Retirement: Are Self-Rated Measures Endogenous?" National Bureau of Economic Research Working Paper No. 6503, Cambridge, MA

Ettner, Susan L. 1996. "New Evidence on the Relationship Between Income and Health" Journal of Health Economics, 15(1), 67-85.

Ettner, Susan L. 2000. “The Relationship Between Labor Market Outcomes and Physical and Mental Health: Exogenous Human Capital or Endogenous Health Production" in David S. Salkever and Alan Sorkin (eds.), Research in Human Capital and Development, Vol. 13: (The Economics of Disability), Stamford, CN: JAI Press, 1-31.

Evans, William and John D. Graham. 1988. "Traffic Safety and the Business Cycle" Alcohol, Drugs, and Driving, 4(1), 31-38.

Fenwick, Rudy and Mark Tausig. 1994. "The Macroeconomic Context of Job Stress" Journal of Health and Social Behavior, 35(3), 266-82.

Forbes, John F. and Alan McGregor. 1984. "Unemployment and Mortality in Post-War Scotland" Journal of Health Economics, 3, 219-57.

Freeman, Donald G. 1999. "A Note on 'Economic Conditions and Alcohol Problems"” Journal of Health Economics, 18(5), 661-670.

Goldney, Robert D. 1997. "Unemployment and Health: A Re-appraisal” International Archives of Occupational and Environmental Health, 70(3), 145-147.

Graham, John D., Bei-Hung Chang, and John S. Evans. 1992. "Poorer is Riskier," Risk Analysis, $12,333-337$.

Gravelle, H.S.E., G. Hutchinson, and J. Stern. 1981. "Mortality and Unemployment: A Critique of Brenner's Time Series Analysis" The Lancet, September 26, 675-9.

Grossman, Michael M. 1972. "On the Concept of Health Capital and the Demand for Health" Journal of Political Economy, 80(2), 223-55.

Hamilton, Vivian H., Philip Merrigan, and Éric Dufresne. 1997. "Down and Out: Estimating the Relationship Between Mental Health and Unemployment" Health Economics, 6(4), 397406.

Idler, Ellen L. and Yael Benyamini. 1997. "Self-Rated Health and Mortality: A Review of Twenty-Seven Community Studies" Journal of Health and Social Behavior, 38(1), 21-37.

Idler, Ellen L. and Stanislav V. Kasl. 1995. "Self-Ratings of Health: Do They Also Predict Functional Ability" Journals of Gerontology: Social Sciences, 50(6), s344-s353. 
Joyce, Theodore and Naci Mocan. 1993. "Unemployment and Infant Health: Time-Series Evidence from the State of Tennessee" Journal of Human Resources, 28(1), 185-203.

Karasek, Robert A. and Töres Theorell. 1990. Healthy Work: Stress, Productivity, and the Reconstruction of Working Life. New York: Basic Books.

Lewis, Glyn and Andy Sloggert. 1998. "Suicide, Deprivation, and Unemployment: Record Linkage Study” British Medical Journal, 317, November 7, 1283-1286.

Manning, Willard G., Joseph P. Newhouse, Naihua Duan, Emmett B. Keeler, Arleen Leibowitz, and M. Susan Marquis. 1987. "Health Insurance and the Demand for Medical Care: Evidence From A Randomized Experiment" American Economic Review, 77(3), 251-277.

Martikainen, Pekka T. and Tapani Valkonen. 1996. "Excess Mortality of Unemployed Men and Women During A Period of Rapidly Increasing Unemployment" The Lancet, 348, October $5,904$.

McAvinchey, Ian D. 1988. "A Comparison of Unemployment, Income, and Mortality Interaction for five European Countries."

Morris, Joan K., Derek G. Cook, A. Gerald Shaper. 1994. "Loss of Employment and Mortality" British Medical Journal, 308, April 30, 1135-1139.

Mortensen, P.B., E. Agerbo, T. Erikson, P. Quin, and N. Westergaard-Nielsen. 2000. "Psychiatric Illness and Risk Factors for Suicide in Denmark" The Lancet, 355, January 1, 9-12.

Mwabu, Germano M. 1988. "Seasonality, The Shadow Price of Time and Effectiveness of Tropical Disease Control Programs" in Herrin, Alejando N. \& Patricia L. Rosenfield (eds.) Economics, Health, and Tropical Diseases, University of the Philippines Press, 259-270.

Pritchett, Lant and Lawrence H. Summers. 1996. "Healthier is Wealthier" The Journal of Human Resources, 31(4), 841-868.

Ruhm, Christopher J. 1995. "Economic Conditions and Alcohol Problems", Journal of Health Economics, 14(5), 583-603.

Ruhm, Christopher J. 2000. “Are Recessions Good for Your Health?” Quarterly Journal of Economics, 115(2), 617-650.

Sokejima, Shigeru and Sadanobu Kagamimori. 1998 "Working Hours as a Risk Factor for Acute Myocardial Infarction in Japan: A Case-Control Study" The British Medical Journal, 317 (September 19), 775-780. 
Stern, J. 1983. "The Relationship between Unemployment, Morbidity, and Mortality in Britain", Population Studies, 37, 61-74.

Vistnes, Jessica P. and Vivian Hamilton. 1995. "The Time and Monetary Costs of Outpatient Care for Children" American Economic Review, 85(2), 117-121.

Wagstaff, Adam. 1985. "Time Series Analysis of the Relationship Between Unemployment and Mortality: A Survey of Econometric Critiques and Replications of Brenner's Studies" Social Science Medicine, 21(9), 985-96. 
Table 1: Predicted Effect of Changes in State Macroeconomic Conditions on Health Status

\begin{tabular}{|c|c|c|c|c|c|c|}
\hline \multirow{2}{*}{ Health Outcome } & \multicolumn{4}{|c|}{ Full Sample } & \multicolumn{2}{|c|}{ Workers } \\
\hline & $\bar{Y}$ & & $\hat{\beta}$ & & $\bar{Y}$ & $\hat{\beta}$ \\
\hline Medical Conditions & & & & & & \\
\hline$\geq 1$ & .4185 & $\begin{array}{l}-.0036 \\
(.0013)\end{array}$ & $\begin{array}{l}-.0061 \\
(.0016)\end{array}$ & $\begin{array}{l}-.0057 \\
(.0019)\end{array}$ & .3222 & $\begin{array}{l}-.0075 \\
(.0021)\end{array}$ \\
\hline \# Conditions & .7232 & $\begin{array}{l}-.0072 \\
(.0027)\end{array}$ & $\begin{array}{l}-.0112 \\
(.0034)\end{array}$ & $\begin{array}{l}-.0101 \\
(.0040)\end{array}$ & .4676 & $\begin{array}{l}-.0114 \\
(.0036)\end{array}$ \\
\hline$\geq 1$ Acute Condition & .2053 & $\begin{array}{l}-.0034 \\
(.0011)\end{array}$ & $\begin{array}{l}-.0056 \\
(.0013)\end{array}$ & $\begin{array}{l}-.0057 \\
(.0016)\end{array}$ & .2150 & $\begin{array}{l}-.0062 \\
(.0019)\end{array}$ \\
\hline$\geq 1$ Chronic Condition & .2132 & $\begin{array}{l}-.0002 \\
(.0010)\end{array}$ & $\begin{array}{l}-.0005 \\
(.0013)\end{array}$ & $\begin{array}{l}4.7 \mathrm{E}-5 \\
(.0015)\end{array}$ & .1072 & $\begin{array}{l}-.0013 \\
(.0014)\end{array}$ \\
\hline $\begin{array}{l}\text { Restricted-Activity Days } \\
\quad \geq 1\end{array}$ & .1366 & $\begin{array}{l}-.0024 \\
(.0009)\end{array}$ & $\begin{array}{l}-.0017 \\
(.0012)\end{array}$ & $\begin{array}{l}-.0005 \\
(.0014)\end{array}$ & .0959 & $\begin{array}{l}-.0022 \\
(.0014)\end{array}$ \\
\hline \# Days & .9132 & $\begin{array}{l}-.0181 \\
(.0069)\end{array}$ & $\begin{array}{l}-.0132 \\
(.0088)\end{array}$ & $\begin{array}{l}-.0031 \\
(.0104)\end{array}$ & .4110 & $\begin{array}{l}-.0085 \\
(.0068)\end{array}$ \\
\hline $\begin{array}{l}\text { Bed-Days } \\
\quad \geq 1\end{array}$ & .0667 & $\begin{array}{l}-.0014 \\
(.0007)\end{array}$ & $\begin{array}{l}-.0011 \\
(.0009)\end{array}$ & $\begin{array}{l}-.0009 \\
(.0010)\end{array}$ & .0483 & $\begin{array}{l}-.0003 \\
(.0010)\end{array}$ \\
\hline \# Days & .3387 & $\begin{array}{l}-.0082 \\
(.0038)\end{array}$ & $\begin{array}{l}-.0062 \\
(.0048)\end{array}$ & $\begin{array}{l}-.0043 \\
(.0058)\end{array}$ & .1349 & $\begin{array}{l}-.0004 \\
(.0031)\end{array}$ \\
\hline $\begin{array}{l}\text { Overall Health Status } \\
\quad \text { Poor }\end{array}$ & .0426 & $\begin{array}{c}.0010 \\
(.0005)\end{array}$ & $\begin{array}{l}8.2 \mathrm{E}-5 \\
(.0007)\end{array}$ & $\begin{array}{l}-.0005 \\
(.0008)\end{array}$ & .0100 & $\begin{array}{l}-.0005 \\
(.0005)\end{array}$ \\
\hline Poor/Fair & .1732 & $\begin{array}{c}.0001 \\
(.0010)\end{array}$ & $\begin{array}{l}-.0017 \\
(.0012)\end{array}$ & $\begin{array}{l}-.0033 \\
(.0015)\end{array}$ & .0944 & $\begin{array}{l}-.0005 \\
(.0013)\end{array}$ \\
\hline State Time Trends & & No & Yes & Yes & & Yes \\
\hline Macroeconomic Proxy & & $\begin{array}{l}\text { Unemployment } \\
\text { (a) }\end{array}$ & $\begin{array}{l}\text { Unemployment } \\
\text { (b) }\end{array}$ & $\begin{array}{l}\text { Nonemployment } \\
\text { (c) }\end{array}$ & & $\begin{array}{l}\text { Unemployment } \\
\text { (b) }\end{array}$ \\
\hline
\end{tabular}


Note: Data are from the National Health Interview Survey, 1969-1981 Cumulative Core File. The sample includes respondents aged 30 and above who were surveyed in 1972-1981 and who resided in one of 31 large SMSAs. Medical conditions indicate acute or chronic ailments at the survey date. The dependent variable in the third row is a dichotomous indicator of whether the individual suffers from one or more acute morbidities (but no chronic conditions). The outcome in the fourth row is a dichotomous indicator of one or more chronic conditions (with or without accompanying acute ailments). Restricted-Activity days refer to days, in the last two weeks, where the individual cut down on "usual" activities due to illness or injury. Bed-days refer to days in the last two weeks that the respondent stayed in bed for most or all of the day due to illness or injury. Overall health status is self-assessed into the categories of "poor", "fair", "good", or "excellent". Linear probability models are estimated, except for the number of restricted-activity days, bed-days, or medical conditions. In these cases, Tobit estimates are obtained. The regression equations also contain state and year dummy variables as well as covariates for age (5), education (4), gender, race (2), veteran status, marital status (3), residence in a

central city and (sometimes) state-specific linear time trends. $\overline{\boldsymbol{Y}}$ displays the average value of the dependent variable and $\hat{\beta}$ shows the predicted effect of a one percentage point rise in the state unemployment or nonemployment rate. The latter are measured by the regression coefficients for the linear probability models and, for the Tobit estimates, by the average value of $\Phi\left(X_{i} \beta / \sigma\right) \beta_{k}$, for $\beta_{k}$ the tobit coefficient on the unemployment rate and $\Phi($.) the predicted probability of a non-censored observation. The sample means and regression estimates are calculated using sampling weights. Robust standard errors are displayed in parentheses. The first four columns show results for the full sample; the last two columns display findings for persons working at the survey date. The number of observations is 217,471 , for the full sample, except for self-assessed health status where it is 216,096. Sample sizes for workers are 121,042 , except for self-assessed health where they are 120,494. 
Table 2:

Predicted Effect of Macroeconomic Conditions on Medical Care Utilization During Past Year

\begin{tabular}{|c|c|c|c|c|c|c|c|c|}
\hline \multirow{2}{*}{$\begin{array}{c}\text { Type of } \\
\text { Medical Care }\end{array}$} & \multicolumn{5}{|c|}{ Full Sample } & \multicolumn{3}{|c|}{ Workers } \\
\hline & $\bar{Y}$ & & & & & $\overline{\boldsymbol{Y}}$ & & 3 \\
\hline \multicolumn{9}{|l|}{ Hospital Episodes } \\
\hline$\geq 1$ & .1185 & $\begin{array}{l}7.5 \mathrm{E}-5 \\
(.0008)\end{array}$ & $\begin{array}{l}-.0011 \\
(.0011)\end{array}$ & $\begin{array}{l}-.0015 \\
(.0013)\end{array}$ & $\begin{array}{l}-.0007 \\
(.0011)\end{array}$ & .0800 & $\begin{array}{l}-.0016 \\
(.0012)\end{array}$ & $\begin{array}{l}-.0012 \\
(.0012)\end{array}$ \\
\hline \# Episodes & .1503 & $\begin{array}{l}.0005 \\
(.0012)\end{array}$ & $\begin{array}{l}-.0011 \\
(.0015)\end{array}$ & $\begin{array}{l}-.0018 \\
(.0018)\end{array}$ & $\begin{array}{c}.0012 \\
(.0015)\end{array}$ & .0925 & $\begin{array}{l}-.0018 \\
(.0015)\end{array}$ & $\begin{array}{l}3.1 \mathrm{E}-5 \\
(.0016)\end{array}$ \\
\hline$\geq 1$ Doctor Visit & .7577 & $\begin{array}{l}-.0012 \\
(.0011)\end{array}$ & $\begin{array}{l}-.0032 \\
(.0014)\end{array}$ & $\begin{array}{l}-.0006 \\
(.0017)\end{array}$ & $\begin{array}{l}-.0021 \\
(.0014)\end{array}$ & .7257 & $\begin{array}{l}-.0027 \\
(.0020)\end{array}$ & $\begin{array}{l}-.0014 \\
(.0020)\end{array}$ \\
\hline State Time Trends & & No & Yes & Yes & Yes & & Yes & Yes \\
\hline $\begin{array}{l}\text { Macroeconomic } \\
\text { Proxy }\end{array}$ & & $\begin{array}{l}\text { Unemploy } \\
\text {-ment }\end{array}$ & $\begin{array}{l}\text { Unemploy } \\
\text {-ment }\end{array}$ & $\begin{array}{l}\text { Nonem- } \\
\text { ployment }\end{array}$ & $\begin{array}{l}\text { Unemploy } \\
\text {-ment }\end{array}$ & & $\begin{array}{l}\text { Unemploy } \\
\text {-ment }\end{array}$ & $\begin{array}{c}\text { Unemploy } \\
\text {-ment }\end{array}$ \\
\hline Health Status & & No & No & No & Yes & & No & Yes \\
\hline Specification & & (a) & (b) & (c) & (d) & & (b) & (d) \\
\hline
\end{tabular}

Note: See note on table 1. The regression equations control for the same covariates as in the corresponding specification of that table. Specification (d) also includes two dummy variables measuring the presence of (one or more) chronic and acute medical conditions. The number of hospital episodes is estimated as a Tobit model. Linear probability estimates are obtained for all other outcomes. The number of observations is 217,471 for hospital episodes and 215,652 for doctor visits for the full sample. For workers, the respective sample sizes are 121,042 and 119,849. 
Table 3:

Predicted Effect of Macroeconomic Conditions for Subgroups

\begin{tabular}{|c|c|c|c|c|c|}
\hline Dependent Variable & $\begin{array}{l}30-55 \\
\text { Year } \\
\text { Olds } \\
\end{array}$ & Men & Women & Whites & Blacks \\
\hline$\geq 1$ Medical Condition & $\begin{array}{l}-.0064 \\
(.0020) \\
{[.3416]}\end{array}$ & $\begin{array}{l}-.0063 \\
(.0023) \\
{[.3951]}\end{array}$ & $\begin{array}{l}-.0059 \\
(.0022) \\
{[.4387]}\end{array}$ & $\begin{array}{l}-.0055 \\
(.0017) \\
{[.4176]}\end{array}$ & $\begin{array}{l}-.0113 \\
(.0044) \\
{[.4484]}\end{array}$ \\
\hline$\geq 1$ Acute Condition & $\begin{array}{l}-.0074 \\
(.0017) \\
{[.2065]}\end{array}$ & $\begin{array}{l}-.0066 \\
(.0019) \\
{[.1846]}\end{array}$ & $\begin{array}{l}-.0047 \\
(.0019) \\
{[.2231]}\end{array}$ & $\begin{array}{l}-.0053 \\
(.0014) \\
{[.2091]}\end{array}$ & $\begin{array}{l}-.0065 \\
(.0036) \\
{[.1868]}\end{array}$ \\
\hline$\geq 1$ Chronic Condition & $\begin{array}{c}.0009 \\
(.0014) \\
{[.1351]}\end{array}$ & $\begin{array}{c}.0003 \\
(.0019) \\
{[.2105]}\end{array}$ & $\begin{array}{l}-.0012 \\
(.0018) \\
{[.2156]}\end{array}$ & $\begin{array}{c}-.0001 \\
(.0014) \\
{[.2085]}\end{array}$ & $\begin{array}{c}-.0048 \\
(.0038)[ \\
2616]\end{array}$ \\
\hline $\begin{array}{l}\geq 1 \text { Restricted-Activity } \\
\text { Day }\end{array}$ & $\begin{array}{l}-.0019 \\
(.0014) \\
{[.1263]}\end{array}$ & $\begin{array}{l}-.0032 \\
(.0016) \\
{[.1165]}\end{array}$ & $\begin{array}{l}-.0004 \\
(.0017) \\
{[.1539]}\end{array}$ & $\begin{array}{l}-.0018 \\
(.0012) \\
{[.1312]}\end{array}$ & $\begin{array}{l}-.0003 \\
(.0036) \\
{[.1815]}\end{array}$ \\
\hline$\geq 1$ Bed-Day & $\begin{array}{l}-.0018 \\
(.0011) \\
{[.0657]}\end{array}$ & $\begin{array}{l}-.0017 \\
(.0011) \\
{[.0551]}\end{array}$ & $\begin{array}{l}-.0006 \\
(.0012) \\
{[.0768]}\end{array}$ & $\begin{array}{l}-.0012 \\
(.0009) \\
{[.0630]}\end{array}$ & $\begin{array}{c}.0003 \\
(.0027) \\
{[.0958]}\end{array}$ \\
\hline Poor Overall Health & $\begin{array}{c}.0004 \\
(.0007) \\
{[.0274]}\end{array}$ & $\begin{array}{l}-.0006 \\
(.0010) \\
{[.0414]}\end{array}$ & $\begin{array}{c}.0007 \\
(.0009) \\
{[.0435]}\end{array}$ & $\begin{array}{c}.0006 \\
(.0007) \\
{[.0379]}\end{array}$ & $\begin{array}{l}-.0029 \\
(.0024) \\
{[.0774]}\end{array}$ \\
\hline $\begin{array}{l}\text { Poor/Fair Overall } \\
\text { Health }\end{array}$ & $\begin{array}{l}-.0005 \\
(.0014) \\
{[.1242]}\end{array}$ & $\begin{array}{c}-.0003 \\
(.0017) \\
{[.1554]}\end{array}$ & $\begin{array}{c}-.0028 \\
(.0017) \\
{[.1884]}\end{array}$ & $\begin{array}{c}-.0007 \\
(.0013) \\
{[.1575]}\end{array}$ & $\begin{array}{l}-.0068 \\
(.0040) \\
{[.2876]}\end{array}$ \\
\hline$\geq 1$ Hospital Episode & $\begin{array}{l}-.0020 \\
(.0013) \\
{[.1034]}\end{array}$ & $\begin{array}{c}-.0011 \\
(.0015) \\
{[.1041]}\end{array}$ & $\begin{array}{l}-.0013 \\
(.0015) \\
{[.1310]}\end{array}$ & $\begin{array}{l}-.0017 \\
(.0012) \\
{[.1175]}\end{array}$ & $\begin{array}{c}.0024 \\
(.0031) \\
{[.1311]}\end{array}$ \\
\hline$\geq 1$ Doctor Visit & $\begin{array}{l}-.0027 \\
(.0018) \\
{[.7451]}\end{array}$ & $\begin{array}{l}-.0036 \\
(.0022) \\
{[.7052]}\end{array}$ & $\begin{array}{l}-.0030 \\
(.0018) \\
{[.8028]}\end{array}$ & $\begin{array}{l}-.0026 \\
(.0015) \\
{[.7751]}\end{array}$ & $\begin{array}{l}-.0080 \\
(.0038) \\
{[.7896]}\end{array}$ \\
\hline
\end{tabular}

Note: See notes on tables 1 and 2. This table shows the predicted effects of a one percentage point increase in the state unemployment rate. The regression models also control for state and year dummy variables, state-specific time trends, and the same personal characteristics as in Tables 1 and 2.

Sample sizes range between 136,099-137,383 for 30-55 year olds and 99,024-100,044, 116,628$117,427,186,978-188,383$, and 24,793-25,146 for men, women, whites, and blacks. Standard errors are in parentheses. Mean values of the dependent variable are in brackets. 
Table 4:

Predicted Effect of Macroeconomic Conditions on Specific Chronic Medical Conditions

\begin{tabular}{|c|c|c|c|c|c|}
\hline Chronic Condition & $\begin{array}{c}\text { Full } \\
\text { Sample }\end{array}$ & Workers & $\begin{array}{l}30-55 \\
\text { Year } \\
\text { Olds } \\
\end{array}$ & Men & Women \\
\hline Heart Disease & $\begin{array}{l}-.0027 \\
(.0075) \\
{[.0552]}\end{array}$ & $\begin{array}{c}-.0064 \\
(.0064 \\
{[.0214]}\end{array}$ & $\begin{array}{c}.0018 \\
(.0066) \\
{[.0247]}\end{array}$ & $\begin{array}{l}-.0031 \\
(.0109) \\
{[.0547]}\end{array}$ & $\begin{array}{l}-.0024 \\
(.0103) \\
{[.0555]}\end{array}$ \\
\hline Ischemic & $\begin{array}{c}-.0072 \\
(.0042) \\
{[.0168]}\end{array}$ & $\begin{array}{l}-.0112 \\
(.0038) \\
{[.0079]}\end{array}$ & $\begin{array}{l}-.0033 \\
(.0034) \\
{[.0065]}\end{array}$ & $\begin{array}{l}-.0165 \\
(.0068) \\
{[.0213]}\end{array}$ & $\begin{array}{c}.0005 \\
(.0052) \\
{[.0129]}\end{array}$ \\
\hline Other & $\begin{array}{c}.0045 \\
(.0064) \\
{[.0383]}\end{array}$ & $\begin{array}{c}.0047 \\
(.0052) \\
{[.0135]}\end{array}$ & $\begin{array}{c}.0051 \\
(.0057) \\
{[.0182]}\end{array}$ & $\begin{array}{c}.0133 \\
(.0088) \\
{[.0334]}\end{array}$ & $\begin{array}{l}-.0029 \\
(.0092) \\
{[.0426]}\end{array}$ \\
\hline Arthritis & $\begin{array}{l}-.0011 \\
(.0062) \\
{[.0368]}\end{array}$ & $\begin{array}{c}.0005 \\
(.0050) \\
{[.0117]}\end{array}$ & $\begin{array}{c}-.0014 \\
(.0050) \\
{[.0145]}\end{array}$ & $\begin{array}{c}.0052 \\
(.0075) \\
{[.0228]}\end{array}$ & $\begin{array}{l}-.0063 \\
(.0095) \\
{[.0489]}\end{array}$ \\
\hline Lung Disease & $\begin{array}{l}-.0032 \\
(.0037) \\
{[.0126]}\end{array}$ & $\begin{array}{c}.0010 \\
(.0033) \\
{[.0056]}\end{array}$ & $\begin{array}{l}-.0014 \\
(.0036) \\
{[.0076]}\end{array}$ & $\begin{array}{l}-.0076 \\
(.0058) \\
{[.0145]}\end{array}$ & $\begin{array}{c}.0005 \\
(.0048) \\
{[.0109]}\end{array}$ \\
\hline Diabetes & $\begin{array}{c}.0010 \\
(.0037) \\
{[.0119]}\end{array}$ & $\begin{array}{l}-.0024 \\
(.0030) \\
{[.0046]}\end{array}$ & $\begin{array}{l}-2.4 \mathrm{E}-5 \\
(.0033) \\
{[.0058]}\end{array}$ & $\begin{array}{l}-.0043 \\
(.0053) \\
{[.0113]}\end{array}$ & $\begin{array}{c}.0057 \\
(.0051) \\
{[.0124]}\end{array}$ \\
\hline Circulatory & $\begin{array}{c}.0028 \\
(.0033) \\
{[.0100]}\end{array}$ & $\begin{array}{c}.0032 \\
(.0024) \\
{[.0037]}\end{array}$ & $\begin{array}{c}.0033 \\
(.0030) \\
{[.0048]}\end{array}$ & $\begin{array}{c}.0059 \\
(.0046) \\
{[.0091]}\end{array}$ & $\begin{array}{c}.0002 \\
(.0047) \\
{[.0108]}\end{array}$ \\
\hline Back Disorders & $\begin{array}{l}-.0087 \\
(.0032) \\
{[.0100]}\end{array}$ & $\begin{array}{l}-.0062 \\
(.0039) \\
{[.0082]}\end{array}$ & $\begin{array}{l}-.0074 \\
(.0042) \\
{[.0103]}\end{array}$ & $\begin{array}{l}-.0083 \\
(.0055) \\
{[.0116]}\end{array}$ & $\begin{array}{l}-.0090 \\
(.0039) \\
{[.0086]}\end{array}$ \\
\hline Stroke & $\begin{array}{l}-.0034 \\
(.0028) \\
{[.0069]}\end{array}$ & $\begin{array}{l}-.0009 \\
(.0012) \\
{[.0009]}\end{array}$ & $\begin{array}{l}-.0018 \\
(.0017) \\
{[.0016]}\end{array}$ & $\begin{array}{l}-.0079 \\
(.0043) \\
{[.0077]}\end{array}$ & $\begin{array}{c}.0007 \\
(.0036) \\
{[.0063]}\end{array}$ \\
\hline Cancer & $\begin{array}{l}-.0010 \\
(.0023) \\
{[.0054]}\end{array}$ & $\begin{array}{l}-.0004 \\
(.0018) \\
{[.0017]}\end{array}$ & $\begin{array}{l}-.0034 \\
(.0020) \\
{[.0026]}\end{array}$ & $\begin{array}{c}.0045 \\
(.0035) \\
{[.0054]}\end{array}$ & $\begin{array}{l}-.0057 \\
(.0031) \\
{[.0054]}\end{array}$ \\
\hline Neurosis & $\begin{array}{c}.0039 \\
(.0026) \\
{[.0054]}\end{array}$ & $\begin{array}{c}.0025 \\
(.0022) \\
{[.0020]}\end{array}$ & $\begin{array}{c}.0022 \\
(.0032) \\
{[.0047]}\end{array}$ & $\begin{array}{c}.0045 \\
(.0042) \\
{[.0054]}\end{array}$ & $\begin{array}{c}.0033 \\
(.0033) \\
{[.0053]}\end{array}$ \\
\hline Central Nervous System & $\begin{array}{l}-.0035 \\
(.0025) \\
{[.0053]}\end{array}$ & $\begin{array}{l}-.0010 \\
(.0019) \\
{[.0019]}\end{array}$ & $\begin{array}{l}-.0040 \\
(.0029) \\
{[.0047]}\end{array}$ & $\begin{array}{l}-.0069 \\
(.0035) \\
{[.0048]}\end{array}$ & $\begin{array}{l}-.0005 \\
(.0035) \\
{[.0058]}\end{array}$ \\
\hline
\end{tabular}


Note: See notes on Tables 1 through 3. The outcomes are dichotomous variables indicating if the respondent has the specified chronic condition at the time of the survey. This table shows the predicted effect of a ten percentage point increase in the state unemployment rate, estimated from linear probability models that include state and year dummy variables, state-specific time trends, and personal characteristics. Sample sizes are 217,471, 121,042, 137,383, 100,044, and 117,427 for the full sample, persons working at the survey date, 30-55 year olds, males, and females. 
Table 5:

Predicted Effect of Macroeconomic Conditions With Controls for Personal Income

\begin{tabular}{|c|c|c|c|}
\hline \multirow[b]{2}{*}{ Dependent Variable } & \multirow{2}{*}{$\begin{array}{c}\text { Model (a) } \\
\text { Unemployment } \\
\text { Rate } \\
\end{array}$} & \multicolumn{2}{|c|}{ Model (b) } \\
\hline & & $\begin{array}{c}\text { Unemployment } \\
\text { Rate }\end{array}$ & $\begin{array}{r}\text { Personal } \\
\text { Income }\end{array}$ \\
\hline$\geq 1$ Medical Condition & $\begin{array}{l}-.0061 \\
(.0016)\end{array}$ & $\begin{array}{l}-.0097 \\
(.0019)\end{array}$ & $\begin{array}{l}-.0262 \\
(.0084)\end{array}$ \\
\hline$\geq 1$ Acute Condition & $\begin{array}{l}-.0056 \\
(.0013)\end{array}$ & $\begin{array}{l}-.0083 \\
(.0016)\end{array}$ & $\begin{array}{l}-.0199 \\
(.0073)\end{array}$ \\
\hline$\geq 1$ Chronic Condition & $\begin{array}{l}-.0005 \\
(.0013)\end{array}$ & $\begin{array}{l}-.0014 \\
(.0016)\end{array}$ & $\begin{array}{l}-.0063 \\
(.0067)\end{array}$ \\
\hline$\geq 1$ Restricted-Activity Day & $\begin{array}{l}-.0017 \\
(.0012)\end{array}$ & $\begin{array}{l}-.0061 \\
(.0014)\end{array}$ & $\begin{array}{l}-.0322 \\
(.0062)\end{array}$ \\
\hline$\geq 1$ Bed-Day & $\begin{array}{l}-.0011 \\
(.0009)\end{array}$ & $\begin{array}{l}-.0042 \\
(.0011)\end{array}$ & $\begin{array}{l}-.0225 \\
(.0045)\end{array}$ \\
\hline Poor Overall Health & $\begin{array}{l}8.2 \mathrm{E}-5 \\
(.0007)\end{array}$ & $\begin{array}{l}-.0007 \\
(.0081)\end{array}$ & $\begin{array}{l}-.0058 \\
(.0034)\end{array}$ \\
\hline Poor/Fair Overall Health & $\begin{array}{l}-.0017 \\
(.0012)\end{array}$ & $\begin{array}{l}-.0017 \\
(.0015)\end{array}$ & $\begin{array}{l}-.0003 \\
(.0063)\end{array}$ \\
\hline$\geq 1$ Hospital Episode & $\begin{array}{l}-.0011 \\
(.0011)\end{array}$ & $\begin{array}{l}-.0011 \\
(.0013)\end{array}$ & $\begin{array}{c}.0001 \\
(.0056)\end{array}$ \\
\hline$\geq 1$ Doctor Visit & $\begin{array}{l}-.0032 \\
(.0014)\end{array}$ & $\begin{array}{l}-.0039 \\
(.0017)\end{array}$ & $\begin{array}{l}-.0051 \\
(.0074)\end{array}$ \\
\hline
\end{tabular}

Note: See notes on Tables 1 and 2. The econometric models control for individual characteristics, state and year dummy variables, state time trends, state unemployment rates and, in model (b), per capita personal incomes (\$1981). The table shows the predicted effect of a one percentage point increase in the unemployment rate or a $\$ 1000$ rise in income. 
Table 6:

Predicted Effect of a Sustained One Percentage Point Increase in Unemployment

\begin{tabular}{|c|c|c|}
\hline Dependent Variable & Contemporaneous Effect & Effect After Two Years \\
\hline$\geq 1$ Medical Condition & $\begin{array}{l}-.0066 \\
(.0020)\end{array}$ & $\begin{array}{c}-.0086 \\
(.0029)\end{array}$ \\
\hline$\geq 1$ Acute Condition & $\begin{array}{l}-.0059 \\
(.0017)\end{array}$ & $\begin{array}{l}-.0097 \\
(.0024)\end{array}$ \\
\hline$\geq 1$ Chronic Condition & $\begin{array}{c}-.0006 \\
(.0016)\end{array}$ & $\begin{array}{c}.0011 \\
(.0023)\end{array}$ \\
\hline$\geq 1$ Restricted-Activity Day & $\begin{array}{l}-.0013 \\
(.0015)\end{array}$ & $\begin{array}{l}-.0037 \\
(.0021)\end{array}$ \\
\hline$\geq 1$ Bed-Day & $\begin{array}{l}-.0014 \\
(.0011)\end{array}$ & $\begin{array}{l}-.0024 \\
(.0015)\end{array}$ \\
\hline Poor Overall Health & $\begin{array}{c}-.0002 \\
(.0009)\end{array}$ & $\begin{array}{c}.0005 \\
(.0012)\end{array}$ \\
\hline Poor/Fair Overall Health & $\begin{array}{c}.0008 \\
(.0017)\end{array}$ & $\begin{array}{l}-.0019 \\
(.0024)\end{array}$ \\
\hline$\geq 1$ Hospital Episode & $\begin{array}{l}-.0013 \\
(.0014)\end{array}$ & $\begin{array}{c}.0023 \\
(.0019)\end{array}$ \\
\hline$\geq 1$ Doctor Visit & $\begin{array}{l}-.0035 \\
(.0018)\end{array}$ & $\begin{array}{l}-.0033 \\
(.0026)\end{array}$ \\
\hline
\end{tabular}

Note: See notes on tables 1 and 2. The first column displays the predicted effects of a one percentage point increase in unemployment that begins in the survey year. The second indicates the impact of a rise in joblessness that began two years earlier and continues through the interview year. These are obtained from regressions that control for individual characteristics, state and year dummy variables, state-specific time trends, and state unemployment rates in years t-2 through t. Sample sizes are 192,350 for self-assessed health, 191,856 for doctor visits, and 193,539 for all other outcomes. 
Table A.1: Sample Means of Explanatory Variables

\begin{tabular}{|c|c|c|c|c|c|}
\hline Variable & $\begin{array}{c}\text { Full } \\
\text { Sample }\end{array}$ & Workers & $\begin{array}{c}30-55 \\
\text { Year Olds }\end{array}$ & Men & Women \\
\hline \multicolumn{6}{|l|}{ Age (in Years) } \\
\hline $40-49$ & .225 & .286 & .357 & .235 & .217 \\
\hline $50-59$ & .222 & 260 & 222 & .230 & .215 \\
\hline $60-69$ & .159 & .100 & ---- & .154 & .163 \\
\hline 70-79 & .092 & .017 & ---- & .078 & .105 \\
\hline$\geq 80$ & .034 & .002 & ---- & .026 & .042 \\
\hline \multicolumn{6}{|l|}{ Education } \\
\hline High School Dropout & .333 & .240 & .243 & .320 & .344 \\
\hline Some College & .139 & .164 & .163 & .147 & .133 \\
\hline College Graduate & .090 & .113 & 107 & .111 & .072 \\
\hline Graduate School & .079 & .112 & .098 & .110 & .051 \\
\hline Not Reported & .021 & .012 & .015 & .021 & .020 \\
\hline Veteran & .260 & .358 & .292 & .535 & .023 \\
\hline Female & .537 & .391 & .519 & ---- & ---- \\
\hline \multicolumn{6}{|l|}{ Race } \\
\hline Black & .123 & .123 & .136 & .117 & .129 \\
\hline Other Nonwhite & .019 & .023 & .024 & .021 & .017 \\
\hline \multicolumn{6}{|l|}{ Marital Status } \\
\hline Married & .714 & .757 & .777 & .801 & .639 \\
\hline Widowed & .118 & .054 & .033 & .048 & .178 \\
\hline Divorced/Separated & .094 & .107 & .112 & .073 & .111 \\
\hline Lives in Central City & .393 & .372 & .367 & .383 & .402 \\
\hline \multicolumn{6}{|l|}{ State Economic Conditions } \\
\hline Unemployment Rate (\%) & 7.01 & 6.97 & 7.00 & 7.01 & 7.02 \\
\hline Nonemployment Rate (\%) & 42.50 & 42.33 & 42.39 & 42.47 & 42.54 \\
\hline Per Capita Income (\$1981) & 11,580 & 11,588 & 11,579 & 11,579 & 11,582 \\
\hline Sample Size & 218,369 & 121,585 & 138,004 & 104,066 & 117,903 \\
\hline
\end{tabular}

Note: Sampling weights are used in calculating variable means. All of the explanatory variables are dichotomous except for the three measure of state economic conditions. The full sample includes respondents aged 30 and above. The second column includes respondents who are employed at the interview date. The samples in last three columns are restricted to $30-55$ year olds, males, and females. The reference groups for age, education, race and marital status are 30-39 year olds, high school graduates, whites, and never married individuals. 
Table A.2: Detailed Regression Results for Selected Health Outcomes

\begin{tabular}{|c|c|c|c|c|}
\hline Explanatory Variable & $\begin{array}{c}\geq 1 \text { Medical } \\
\text { Condition }\end{array}$ & $\begin{array}{c}\geq 1 \\
\text { Restricted } \\
\text { Activity Day }\end{array}$ & $\begin{array}{l}\text { Poor Overall } \\
\text { Health }\end{array}$ & $\begin{array}{c}\geq 1 \text { Hospital } \\
\text { Episode }\end{array}$ \\
\hline \multicolumn{5}{|l|}{ Age (in years) } \\
\hline \multirow[t]{2}{*}{$40-49$} & .0312 & -.0092 & .0104 & -.0126 \\
\hline & $(.0029)$ & $(.0021)$ & $(.0010)$ & $(.0019)$ \\
\hline \multirow[t]{2}{*}{$50-59$} & .1101 & .0047 & .0298 & .0031 \\
\hline & $(.0031)$ & $(.0022)$ & $(.0012)$ & $(.0021)$ \\
\hline \multirow[t]{2}{*}{$60-69$} & .1991 & .0112 & .0400 & .0243 \\
\hline & $(.0035)$ & $(.0025)$ & $(.0015)$ & $(.0024)$ \\
\hline \multirow[t]{2}{*}{ 70-79 } & .2762 & .0141 & .0406 & .0056 \\
\hline & $(.0044)$ & $(.0033)$ & $(.0021)$ & $(.0032)$ \\
\hline \multirow[t]{2}{*}{$\geq 80$} & .3820 & .0340 & .0571 & .0880 \\
\hline & $(.0062)$ & $(.0053)$ & $(.0038)$ & $(.0053)$ \\
\hline \multicolumn{5}{|l|}{ Education } \\
\hline \multirow[t]{2}{*}{ High School Dropout } & .0603 & .0328 & .0362 & .0156 \\
\hline & $(.0027)$ & $(.0020)$ & $(.0012)$ & $(.0019)$ \\
\hline \multirow[t]{2}{*}{ Some College } & .0115 & .0059 & -.0042 & -.0034 \\
\hline & $(.0033)$ & $(.0024)$ & $(.0011)$ & $(.0022)$ \\
\hline \multirow[t]{2}{*}{ College Graduate } & -.0209 & -.0095 & -.0096 & -.0133 \\
\hline & $(.0039)$ & $(.0026)$ & $(.0011)$ & $(.0025)$ \\
\hline \multirow[t]{2}{*}{ Graduate School } & -.0023 & -.0032 & -.0132 & -.0179 \\
\hline & $(.0042)$ & $(.0028)$ & $(.0011)$ & $(.0026)$ \\
\hline \multirow[t]{2}{*}{ Not Reported } & -.0372 & -.0034 & .0362 & -.0057 \\
\hline & $(.0074)$ & $(.0053)$ & $(.0042)$ & $(.0051)$ \\
\hline \multirow[t]{2}{*}{ Veteran } & -.0042 & .0034 & -.0020 & .0016 \\
\hline & $(.0030)$ & $(.0021)$ & $(.0013)$ & $(.0020)$ \\
\hline \multirow[t]{2}{*}{ Female } & .0167 & .0303 & -.0046 & .0227 \\
\hline & $(.0027)$ & $(.0019)$ & $(.0012)$ & $(.0018)$ \\
\hline \multicolumn{5}{|l|}{ Race } \\
\hline \multirow[t]{2}{*}{ Black } & .0231 & .0331 & .0273 & .0102 \\
\hline & $(.0035)$ & $(.0028)$ & $(.0019)$ & $(.0025)$ \\
\hline \multirow[t]{2}{*}{ Other Nonwhite } & -.1248 & -.0457 & -.0015 & -.0170 \\
\hline & $(.0072)$ & $(.0048)$ & $(.0028)$ & $(.0046)$ \\
\hline \multicolumn{5}{|l|}{ Marital Status } \\
\hline \multirow[t]{2}{*}{ Married } & -.0325 & -.0091 & -.0095 & .0183 \\
\hline & $(.0041)$ & $(.0029)$ & $(.0018)$ & $(.0026)$ \\
\hline \multirow[t]{2}{*}{ Widowed } & .0115 & .0198 & -.0040 & .0096 \\
\hline & $(.0053)$ & $(.0039)$ & $(.0025)$ & $(.0036)$ \\
\hline \multirow[t]{2}{*}{ Divorced/Separated } & .0545 & .0529 & .0138 & .0387 \\
\hline & $(.0053)$ & $(.0041)$ & $(.0025)$ & $(.0035)$ \\
\hline \multirow[t]{2}{*}{ Lives in Central City } & .0029 & .0067 & .0067 & .0014 \\
\hline & $(.0023)$ & $(.0017)$ & $(.0010)$ & $(.0016)$ \\
\hline \multirow[t]{2}{*}{ State Unemployment Rate (\%) } & -.0036 & -.0024 & .0010 & $7.3 \mathrm{E}-5$ \\
\hline & $(.0013)$ & $(.0009)$ & $(.0005)$ & $(.0008)$ \\
\hline
\end{tabular}


Note: See note on Table 1. The samples and regression models are the same as in model (a) of that table. In addition to the covariates shown, vectors of state and year dummy variables are included. 